\title{
Nomenclatural type of orders: corrections necessary according to Rules 15 and 21 a of the Bacteriological Code (1990 Revision), and designation of appropriate nomenclatural types of classes and subclasses. Request for an Opinion
}

\author{
J. P. Euzéby ${ }^{1}$ and B. J. Tindall ${ }^{2}$
}

Author for correspondence: B. J. Tindall. Tel: +49531 2616 224. Fax: +49 5312616418. e-mail: bti@dsmz.de

1 Ecole Nationale Vétérinaire, 23 chemin des Capelles, 31076 Toulouse cedex 3, France

2 DSMZ-Deutsche Sammlung von Mikroorganismen und Zellkulturen $\mathrm{GmbH}$, Mascheroder Weg 1b, D-38124 Braunschweig, Germany

\begin{abstract}
An important aspect of the Bacteriological Code (1990 Revision) is the designation of nomenclatural types to the various taxonomic ranks to provide a suitable reference point for the unambiguous identification of the taxon. Although the nomenclatural type of the species is the designated strain, and the nomenclatural type of the genus is the type species, the nomenclatural type of both the family and the order is the 'genus on whose name the name of the relevant taxon is based'. However, in some cases a genus has not been designated as the nomenclatural type of an order. Twelve cases that are contrary to the Rules listed and appropriate corrections are proposed. In addition, several classes have been named for which no nomenclatural type has been designated; this brings into question whether they can be considered to have been validly published, as well as highlighting the fact that they would be/are illegitimate.
\end{abstract}

Keywords: nomenclatural type, orders, Bacteriological Code (1990 Revision)
The designation of nomenclatural types under the Bacteriological Code (1990 Revision; Lapage et al., 1992 ) is covered by Rules 15-22. Whilst Rule 15 designates a strain as the nomenclatural type of a species, and Rule $20 \mathrm{a}$ as a species as the nomenclatural type of a genus, Rule 21a of the Bacteriological Code (1990 Revision; Lapage et al., 1992) states that 'the nomenclatural type of a taxon above genus, up to and including order, is the genus on whose name the name of the relevant taxon is based'. Table 2 of Rule 15 also designates the genus as the nomenclatural type for the categories subtribe, tribe, subfamily, family, suborder and order. In some cases, it has been assumed that the nomenclatural type of an order is one of the families included when the name was validly published (cf. Rule 20a). However, such an assumption is contrary to Rule 21a, and names that are contrary to the Rules are illegitimate [Rule 23a (ii), Note 5; Lapage et al., 1992]. Although the Bacteriological Code (1990 Revision; Lapage et al., 1992) makes reference to problems with the naming of families (Rule 21b) and taxa higher than orders (Rule 22), no such provision is made in the
Code for the names of orders not made in conformity with Rule 21a. In such instances, Rules 3 and 4 can be applied. We, therefore, request that the following corrections be made to the designated nomenclatural type of the orders given below.

To avoid confusion, we propose the following corrections (references to effective and valid publication of the names cited below can be found in the List of Bacterial Names with Standing in Nomenclature; Euzéby, 1997; http://www.bacterio.cict.fr/).

Acholeplasmatales Freundt et al. 1984: the nomenclatural type is the genus Acholeplasma Edward and Freundt 1970 (Approved Lists 1980), not the genus Acholeplasma Edward and Freundt 1970 (Approved Lists 1980) and the family Acholeplasmataceae Edward and Freundt 1970 (Approved Lists 1980) as cited in the paper by Freundt et al. (1984).

Halanaerobiales corrig. Rainey and Zhilina 1995: the nomenclatural type is the genus Halanaerobium corrig. Zeikus et al. 1984, not the family Halanaerobiaceae 
corrig. Oren et al. 1984 as cited in Validation List no. 55 (Rainey \& Zhilina, 1995).

Halobacteriales Grant and Larsen 1989: the nomenclatural type is the genus Halobacterium ElazariVolcani 1957 (Approved Lists 1980), not the family Halobacteriaceae Gibbons 1974 (Approved Lists 1980) as cited in Validation List no. 31 (Grant \& Larsen, 1989a). It should be noted that the nomenclatural type of the order Halobacteriales, as published in the effective publication, is the genus Halobacterium (Grant \& Larsen, 1989b) and not the family Halobacteriaceae, as cited on Validation List no. 31 (Grant \& Larsen, 1989a).

Methanobacteriales Balch and Wolfe 1981: the nomenclatural type is the genus Methanobacterium Kluyver and van Niel 1936 (Approved Lists 1980), not the family Methanobacteriaceae Barker 1956 (Approved Lists 1980) as cited in Validation List no. 6 (Balch \& Wolfe, 1981a).

Methanococcales Balch and Wolfe 1981: the nomenclatural type is the genus Methanococcus Kluyver and van Niel 1936 emend. Barker 1936 (Approved Lists 1980), not the family Methanococcaceae Balch and Wolfe 1981 as cited in Validation List no. 6 (Balch \& Wolfe, 1981b).

Methanomicrobiales Balch and Wolfe 1981: the nomenclatural type is the genus Methanomicrobium Balch and Wolfe 1981, not the family Methanomicrobiaceae Balch and Wolfe 1981 as cited in Validation List no. 6 (Balch \& Wolfe, 1981c).

Planctomycetales Schlesner and Stackebrandt 1987: the nomenclatural type is the genus Planctomyces Gimesi 1924 (Approved Lists 1980), not the family Planctomycetaceae Schlesner and Stackebrandt 1987 as cited in Validation List no. 23 (Schlesner \& Stackebrandt, 1987).

Prochlorales (ex Lewin 1977) Florenzano et al. 1986: the nomenclatural type is the genus Prochloron (ex Lewin 1977) Florenzano et al. 1986, not the family Prochloraceae (ex Lewin 1977) Florenzano et al. 1986 as cited in the paper by Florenzano et al. (1986).

Sulfolobales Stetter 1989: the nomenclatural type is the genus Sulfolobus Brock et al. 1972 (Approved Lists 1980), not the family Sulfolobaceae Stetter 1989 as cited in Validation List no. 31 (Stetter, 1989).

Thermococcales Zillig et al. 1988: the nomenclatural type is the genus Thermococcus Zillig et al. 1983, not the family Thermococcaceae Zillig et al. 1988 as cited in Validation List no. 24 (Zillig et al., 1988).

Thermoproteales Zillig and Stetter 1982: the nomenclatural type is the genus Thermoproteus Zillig and Stetter 1982, not the family Thermoproteaceae Zillig and Stetter 1982 as cited in Validation List no. 8 (Zillig $\&$ Stetter, 1982).

Verrucomicrobiales Ward-Rainey et al. 1996: the nomenclatural type is the genus Verrucomicrobium Schlesner 1988, not the family Verrucomicrobiaceae
Ward-Rainey et al. 1996 as cited in Validation List no. 57 (Ward-Rainey et al., 1996).

In addition, the class Proteobacteria Stackebrandt et al. 1988 (Stackebrandt et al., 1988) was proposed without the designation of a nomenclatural type. Whilst the Bacteriological Code (1990 Revision; Lapage et al., 1992) specifies that the nomenclatural type of a class is one of the contained orders (Rule 22), the Approved Lists of Bacterial Names (amended edition; Skerman et al., 1989) states, on p. 1, that 'no nomenclatural type is required for the categories of division, class, or subclass', thus making all names of classes and subclasses included on this list illegitimate according to Rules 15 and 22. Rule 22 also states that 'if not designated, the type of a taxon higher than order may be designated by an Opinion of the Judicial Commission'. In view of our changing appreciation of the taxonomy of prokaryotes, many of the names of classes included on the Approved Lists of Bacterial Names (amended edition; Skerman et al., 1989) are not currently in use, with the exception of the class Actinomycetes Krasil'nikov 1949 (Skerman et al., 1989). It should also be noted that 'a name of a new taxon is not validly published unless ... the type is designated ...' [Rule 27(3)], and the Judicial Commission is therefore asked to rule on the status of class and subclass names published contrary to Rules 22 and 27 , and to designate appropriate nomenclatural types for such names of classes or subclasses if necessary.

\section{References}

Balch, W. E. \& Wolfe, R. S. (1981a). Methanobacteriales ord. nov. In Validation of the Publication of New Names and New Combinations Previously Effectively Published Outside the IJSB, List no. 6. Int J Syst Bacteriol 31, 215-218.

Balch, W. E. \& Wolfe, R. S. (1981b). Methanococcales ord. nov. In Validation of the Publication of New Names and New Combinations Previously Effectively Published Outside the IJSB, List no. 6. Int J Syst Bacteriol 31, 215-218.

Balch, W. E. \& Wolfe, R. S. (1981c). Methanomicrobiales ord. nov. In Validation of the Publication of New Names and New Combinations Previously Effectively Published Outside the IJSB, List no. 6. Int J Syst Bacteriol 31, 215-218.

Euzéby, J. P. (1997). List of Bacterial Names with Standing in Nomenclature: a folder available on the Internet (http:// www.bacterio.cict.fr/). Int J Syst Bacteriol 47, 590-592.

Florenzano, G., Balloni, W. \& Materassi, R. (1986). Nomenclature of Prochloron didemni (Lewin 1977) sp. nov., nom. rev., Prochloron (Lewin 1976) gen. nov., nom. rev., Prochloraceae fam. nov., Prochlorales ord. nov., nom. rev. in the class Photobacteria Gibbons and Murray 1978. Int J Syst Bacteriol 36, 351-353.

Freundt, E. A., Whitcomb, R. F., Barile, M. F., Razin, S. \& Tully, J. G. (1984). Proposal for elevation of the family Acholeplasmataceae to ordinal rank: Acholeplasmatales. Int $J$ Syst Bacteriol 34, 346-349.

Grant, W. D. \& Larsen, H. (1989a). Halobacteriales ord. nov. In Validation of the Publication of New Names and New Combinations Previously Effectively Published Outside the IJSB, List no. 31. Int J Syst Bacteriol 39, 495-497. 
Grant, W. D. \& Larsen, H. (1989b). Group III. Extremely halophilic archaeobacteria. Order Halobacteriales ord. nov. In Bergey's Manual of Systematic Bacteriology, vol. 3, pp. 2216-2218. Edited by J. T. Staley, M. P. Bryant, N. Pfennig \& J. G. Holt. Baltimore: Williams \& Wilkins.

Lapage, S. P., Sneath, P. H. A., Lessel, E. F., Skerman, V. B. D., Seeliger, H. P. R. \& Clark, W. A. (editors) (1992). International Code of Nomenclature of Bacteria (1990 Revision). Bacteriological Code. Washington, DC: American Society for Microbiology.

Rainey, F. A. \& Zhilina, T. N. (1995). Haloanaerobiales ord. nov. In Validation of the Publication of New Names and New Combinations Previously Effectively Published Outside the IJSB, List no. 55. Int J Syst Bacteriol 45, 879-880.

Schlesner, H. \& Stackebrandt, E. (1987). Planctomycetales ord. nov. In Validation of the Publication of New Names and New Combinations Previously Effectively Published Outside the IJSB, List no. 23. Int J Syst Bacteriol 37, 179-180.

Skerman, V. B. D., McGowan, V. \& Sneath, P. H. A. (editors) (1989). Approved Lists of Bacterial Names, amended edition. Washington, DC: American Society for Microbiology.
Stackebrandt, E., Murray, R. G. E. \& Trüper, H. G. (1988). Proteobacteria classis nov., a name for the phylogenetic taxon that includes the 'purple bacteria and their relatives'. Int $J$ Syst Bacteriol 38, 321-325.

Stetter, K. O. (1989). Sulfolobales ord. nov. In Validation of the Publication of New Names and New Combinations Previously Effectively Published Outside the IJSB, List no. 31. Int J Syst Bacteriol 39, 495-497.

Ward-Rainey, N., Rainey, F. A., Schlesner, H. \& Stackebrandt, E. (1996). Verrucomicrobiales ord. nov. In Validation of the Publication of New Names and New Combinations Previously Effectively Published Outside the IJSB, List no. 57. Int J Syst Bacteriol 46, 625-626.

Zillig, W. \& Stetter, K. O. (1982). Thermoproteales ord. nov. In Validation of the Publication of New Names and New Combinations Previously Effectively Published Outside the IJSB, List no. 8. Int J Syst Bacteriol 32, 266-268.

Zillig, W., Holz, I., Klenk, H. P., Trent, J., Wunderl, S., Janekovic, D., Imsel, E. \& Haas, B. (1988). Thermococcales ord. nov. In Validation of the Publication of New Names and New Combinations Previously Effectively Published Outside the IJSB, List no. 24. Int J Syst Bacteriol 38, 136-137. 